\title{
( The Brand Personality: a Key Catalyst of the aße Consumer-brand Relationship
}

\section{Maryem Trabelsi}

Assistant Professor, Al Jouf University, Sakakah, SAUDI ARABIA

*E-mail for correspondence: meriem.trabelsi55@yahoo.com

No Conflict of Interest: Declared

\begin{abstract}
In our post-modern era, the brand is perceived more than a simple means of identification of the producer and a tool of differentiation and distinctiveness. From the consumer's angle, it is seen as a partner in a deep, affective and long-lasting relationship that reflects his personality, values, social status, ideology, world view to match with this new perception, managers should infuse their brands with distinctive traits that match with the current and potential customers' needs and identification desire. This research goes in this stream of studies that focus on brand personality and its ability to create, develop and maintain a strong consumer-brand tie. The findings showed that Private Labels' personality is capabe enough to generate trust and attachment in the Tunisian context.
\end{abstract}

Keywords: brand personality, consumer-brand relationship, brand attachment, brand trust, Private Labels

\section{INTRODUCTION}

The several social, ideological, economic and political changes that the whole world has known have greatly influenced many domains theoretically and operationally. Marketing is one of those diverse disciplines that were affected by those mutations. In fact, a simple observation of the marketing thought and practice reveals that it was oriented towards a new philosophy deeply grounded on relational aspect that considers the consumer-brand relationship as a continuous and enduring emotional exchange (Aaker, 1997; Fournier, 1998). Therefore, "the ultimate goal of marketing" has become the generation of "an intense bond between the consumer and the brand" (Hiscock 2001, p1). Hence, the personalized and individualized management as well as the one to one marketing appeared to hold all those changes and highlight the consumers' new brand assessment and perception.

Apart from the emergence of those new ways to deal with the customer and allow companies to meet consumers' evolving needs and desires, many scholars are concentrating their efforts on the search of efficient means to attract new customers, retain them and gain their loyalty. This search is justified by the inability of the classic techniques of attraction based only on the emphasis on the brand's quality and the utilitarian functions to guarantee the corporations' prosperity and success (Van Reckom. J.,
Jacobs. G and Verlegh. P.W.J; 2006). As a matter of fact, today's customers are no more faithful to a unique reference group that can influence their choices and tastes but they belong at the same time to many groups even having divergent and antagonist values and goals which harden the marketing managers' responsibility and incite them to find out new ways to intrigue and stimulate the customer' attention.

The focus on an enduring and persistent emotional relationship is the focal point of this new stream of marketing researches. The studies following this vision showed that the customer and the brand are active partners (Fournier, 1998), their bond is a series of reciprocal emotional and values exchange. In fact, the new consumers do not accept anymore a tie that considers them as simple receivers or passive party (Samama, 2003). Moreover, such studies noticed that brands are more than a simple mark of differentiation in a store full of competitive ones as they are considered by postmodern customers as a means of selfexpression and identification for which they show respect, trust, attachment and love (Belk, 1988; Brown, 1997; Fournier, 1998; Ambroise, 2006; Albert; Merunka and Valette-Florence,2007) Thus, the customer-brand relationship is henceforth an affective one that must be apprehended and examined from a new angle. 
In fact, a common point between all the well-known brands is that they succeeded to create distinct and unique personalities in the eyes of their consumers (Van Reckom. J.; Jacobs. G. and Verlegh. P.W.J; 2006). Thus, the brand is no more considerated as a mute entity but on the contrary it seems to have, like any human being, a life style, values, an identity and exclusive personality traits. In other words, the brand has become a vital entity through which consumers convey messages about their tastes, values, social class and so forth to their surroundings. Consequently, the brand anthropomorphization and personality "has come to the forefront of marketing thinking" (Blyth, 2007, p284) and its understanding became the subject of a substantial and notable interest among marketing theorists and practitioners.

The study in hand follows this research stream that focuses on BP and examines the nature and the depth of customerbrand relationships. Particularly, it addresses two questions. First is to which extent the BP influences the relationship that customers have with a particular brand? In other words are the BP traits able to affect positively the development and the evolvement of the brand trust (BT) and brand attachment (BA) feelings? Second, what is the role that brand sensitivity (BS) may play in the relationship BP- BT and BP-BA? The objective is to know if BS may intensify the relationship between $\mathrm{BP}$ and the aforesaid concepts.

The article is structured as follows: First, we start with the literature review that presents the research concepts. Second, we expose the methodology and finally we present and discuss the results.

\section{LITERATURE REVIEW}

\section{Brand personality}

For a long time, the attention of many scholars was paid to the analysis and the conceptualization of human personality and to which extent it influences the choice and the consumers' reactions towards specific brands but little interest was devoted in consumer behavior to brand personality.

The first people who have used this concept were the marketing practitioners more precisely the advertisers but its emergence in the theory dates back to 1958 when Martineau (1958, p144) defined it as "all the non-material cues of a product" that are able to distinguish the latter from its competitors in the consumers' eyes. Apart from their physical (material) and functional aspects, brands are viewed as encompassing some human personality traits and "consumers do choose them the same way they choose their friends" (King, 1970, p144).

In this research stream, researchers endeavored to define the concept as "the set of symbolic attributes" (Plummer, 1984), "the character of a brand" (Seguela, 1982) and the materialization of the brand image using words generally attributed to human beings (Keller, 1993) but no attempt to measure it was done till 1997 when Aaker developed a theoretical framework of brand personality construct in which the following definition was presented "...a set of human characteristics associated with a brand" which means that when choosing a brand, the consumer infuses human traits into brands. In fact, the notion of brand personality is extremely important in crowded and mature markets where quality is no more a privilege and is taken as granted and revolutionary features of products are difficult to create and when created they are easily imitated by rivals.

Although the fame of the Aaker's brand personality definition, it was criticized. For instance, Ambroise et al (2006) claimed that the main weakness of the definition is that it comprises some traits that are exclusive to brands and have no equivalent in human personality. According to those authors, in order to facilitate to the consumers the projection of their own traits on the brand, all the noncommon features between brand personality and the human one must be eliminated or at least decreased. To do so, Ambroise et al (2006) presented an alternative definition where brand personality is "...a set of traits of human personality associated with a brand".

\section{Brand attachment}

The concept of attachment as many relational concepts used in marketing research literature finds its sources in the interpersonal psychology, the first studies focused on the relationship mother-child as a compulsory base "to grow up mentally healthy" (Bowbly,1951, p765), love relationships (Hazan and Shaver, 1994) and friendship links (Weis, 1988; Trinke and Bartholomev, 1997). Those relations are characterized by feelings of affiliation and proximity that can be transferred according to many psychologists and researchers (Csikszentmihlyi and Rochberg Halton, 1981; Belk, 1992; Richins, 1994) to materials and objects. This transposition to objects interested a lot of scholars who tried to understand the nature of attachment to possessions (Csikszentmihalyi and Rochberg-Halton, 1981; Bloch et Richens, 1983; Wallendorf and Arnould, 1988; Belk, 1992; Richens, 1994) and the value and the expressive function of consumption in the customers' eyes.

The concept of attachment was finally transposed to brands in the nineties when the number of researches on brand equity increased and "branding a product is projecting it in a symbolic universe and associating it not only with tangible and intangible benefits but also with ideas, emotions and values" (Heilbrunn, 1997, p1974). It is indispensable to mention that the customer is not related or attached to the object and its mere utility but to the mysterious and symbolic benefits taken from its possession and use the same psychological ones taken from knowing a star or a famous person.

Brand attachment (BA) is a crucial and essential concept in explaining the type and the depth of the relationship 
customer-brand, not only, for scholar but also, for practitioners and managers who endeavor to restrain their customers in a market characterized by fierce competition and mass communication. Several definitions of attachment have been suggested but they all emphasize its psychological, emotional and affective components.

According to Cristau (2001, p13), BA "is a enduring psychological, emotional and interactive relationship between the customer and the brand where the affective grade is expressed by dependence and friendship characteristics". This definition stresses on the emotional aspect of the attachment and highlights that the brand attachment consists on the simultaneous conjunction of dependence (the customer relies on the brand to fulfill his/her requirements, needs, desires and to carry out their expectations) and friendship (mutual concessions, give and take, sacrifices to satisfy the partner and shared benefits)

A second definition was presented by Heilbrunn (2001, p10) in which the attachment refers to "the intensity of the emotional and the affective link between customer and brand", this definition is based on a transposition of the interpersonal attachment in social psychology to the world of brands. A third definition was presented by Lacoeuilhe (2000) in which the attachment is considered as a psychological variable, independent of a purchase context and does not lean on the extrinsic or intrinsic features of the product, this psychological variable is expressed through a long and inalienable affective reaction towards the brand.

\section{Brand Trust}

One of the most important concepts used to examine the depth of brand-individual relationship is brand trust that gained a great interest among marketing scholars. This can be explained by the evolving number of crisis and unethical practices used by some firms. In this regard, Bainbridge (1997, p13) asserted that "a trustworthy brand places the consumer at the center of its world and relies more on understanding real consumer needs and fulfilling them than the particular service or product. It is not merely responsive, but responsible".

According to Romaniuk and Bogomolova (2005), trust is a "hygiene" factor that all the competing brands must have in order to be more competitive. It is a positive reputation validated by a third party in a long-term relationship (Bloy, 1996). Trust does exit "when one party has confidence in an exchange partner's reliability and integrity" (Morgan and Hunt, 1994, p23). BT refers to the ability of the brand to satisfy all the customer's requirements and to live up to any promises. Aside from needs satisfaction and promises fulfillment, the brand trust is the result of successful past interactions with the brand. BT has been also defined as "the willingness of the average consumer to rely on the ability of the brand to perform its stated function" (Chaudhuri and Holbrook, 2001, p13, 14).
A recent research undertaken by Ballester and Munuera Aleman (2002, p12) defines BT as "a feeling security held by the consumer in his/her interaction with the brand, that it is based on the perceptions that the brand is reliable and responsible for the interests and welfare of the consumer. "Thus, BT is a belief in the brand based on both the credibility of the company broadcasting this brand and the importance that it gives to the consumer satisfaction. According to Gurviez (1999, p20), BT, from a consumer view, is "the presumption that the brand, as a personified entity, commits itself to produce a predictable reaction (behavior) consistent with the customer's expectations and to support this orientation in the future with benevolence"

\section{Brand Sensitivity}

The importance of this concept is in no case inferior to the importance of the precedent concepts. In fact, it seems obvious that if a customer who does not pay any attention to brands cannot be attached emotionally to any one of them despite all the marketing efforts, a customer who considers the brand a simple name pasted on the packaging of a brand and bases their choice on rational factors cannot even think about trust.

Kapferer (1992) tried to shed light and explain the importance of BS in the consumer behavior research as well as its motives and consequences for consumers and companies' brand management approaches and strategies.

The concept was defined as a psychological variable that involves different components such as:

- The importance given to the brand in the decisionmaking process.

- The loading of the brand compared to the other product attributes.

- The importance attributed to the brand in the information research.

- The order of the brand acquisition as a piece of information

According to the author, brand sensitivity does exist when the customer insists to know the brand name and that this piece of information influences deeply their purchase decisions and plays a crucial role in their choice and the way they compare the offered brands and the available alternatives as well as the amount of sacrifices that they are able to do.

\section{Research Methodology}

\section{Research Objectives}

Despite the tremendous number of studies that examined the relationship brand-consumer, the impact of brand personality on this delicate tie through its positive influence on many relational variables, the marketing literature suffers from a lack of studies devoted to the Retailer-brands- Consumer bond. In fact, the majority of scholars and practitioners were interested by the Private Labels Consumer's Profile, their perceived quality, the consumers' satisfaction with them. 
One of those rare researches that examined the relationship Distributor Brands' Consumers was the Cristau and Lacouilhe (2008) one that treated the impact of brand attachment on brand loyalty. But a gap is still exist concerning the personality of those brands and how it helps in the creation and the evolution of the tie Private LabelsConsumers. In the light of the absence of researches treating the role of brand personality in this tie, the current study is indispensable and imperative in order to fill in this hole.

The main objective of this research is to examine the impact of the different BP traits on the consumer-brand relationship through their impact on BT and BA. Moreover, the study aims to find out the consumer's characteristics that may influence this relationship. Particularly, the study aims to:

- Identify the extent to which the BP concept is able to stimulate the development and the maintaining of a strong and deep consumer-brand relationship. In other words, this will allow to find out if previous studies findings are consistent in a particular non Western (Tunisia) context.

- Find out the ability of BS to influence positively the impact of BP traits on the RB-consumer relationship. By achieving this objective, we try to find some answers to the question: to which degree the consumer brands sensitivity (CBS) level affects the relationship between RBP and BA and RBP-BT?

\section{Research Hypotheses}

The revolutionary concept of brand personality succeeded in many countries in creating faithful customers who have resisted and refused all the competitive offers, stuck by their brands and developed an enduring and strong relationship with them. This influence of brand personality on consumerbrand relationship will be apprehended by the influence of brand personality on one hand on brand attachment and on the other hand on brand trust or brand confidence. This idea is summarized in the first hypothesis that postulates that:

$\mathbf{H}_{1}$ : It influences positively the brand trust (BT)

$\mathbf{H}_{2}$ : It influences positively the brand attachment (BA)

According to Gouteron (2006), the BS plays a crucial role in deepening the impact that BP has on BA and BT. His research demonstrated that some dimensions of the brand personality have a strong influence on the brand trust especially for people who are strongly sensitive to brands but the study rejected the mediator role of BS between BP and BA. The test of the role of BS on the relationship consumer-brand will be examined in the current research as it was tested in a French context in the feminine Readyto-wear sector. This positive influence is presented in the following hypothesis:

$\mathbf{H}_{3}$ : Brand sensitivity influences positively the relationship BP-BT

$\mathbf{H}_{4}$ : Brand sensitivity influences positively the relationship BP-BA

\section{The conceptual model}

The conceptual model guiding this research is depicted in the following figure. The proposed model draws from Gouteron (2006) study in the ready-to-wear sector in the French context.

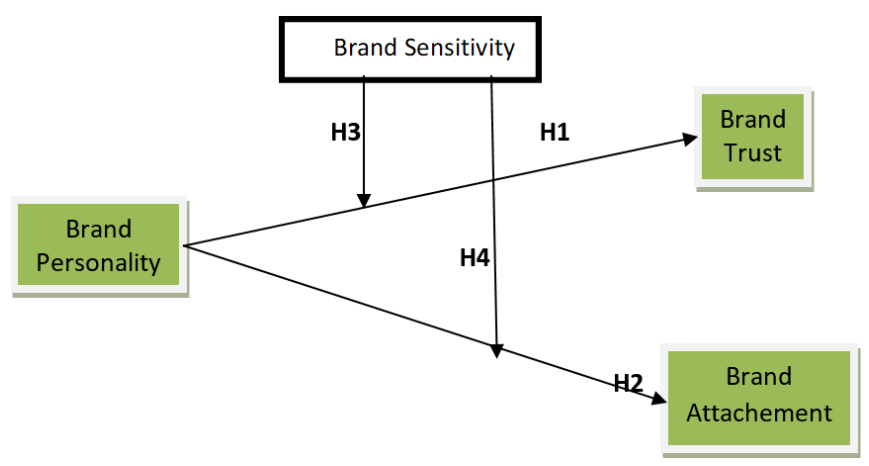

Figure 1: The conceptual model

\section{The variables operationalization}

In order to measure the retailer brands personality, the sacle that was developed by Trabelsi (2010) in a Tunisian context and that is composed of three factors (Excitation, Fallacious character and Modernity) and 14 items was used. After having compared the different scales that were developed in the francophone context, the unidimensional scale of Lacoeuilhe (2000) will be used in this research thanks to the consistency that it proved when used in many studies such as in Gouteron (2006) article, in Smaoui (2008) and many other researches as well as its reliability that was calculated by both the Cronbach's Alpha (0.830) and the $\rho$ de Joreskog (0.890). The scale of Gurviez, Korchia (2002) with eight items will be used in the current research; this conception presents Brand Trust as a tridimensional construct composed of 8 items distributed upon the three factors (Credibilty, Integrity and Benevolence). Finally, the unideimensional scale of Kapferer and Laurent (1992) was used to assess brand sensitivity.

\section{The sample and data collection method}

As it is impossible to get a nominative and exhaustive list of all the Retailer Brands consumers in Tunisia, the research was spread on the area of Big Tunis among 256 consumers using a convenience method. Questionnaires were given to participants in order to be filled in.

\section{RESEARCH RESULtS \\ The Scales Reliabilty and Fiability}

After having coded and seized the data that was presented by the 256 questionnaires, the analysis began and took into account some predefined objectives and universally wellknown criteria. The results for BP gave the same structure of the original scale with a satisfactory and good reliability level (Cronbach's Alpha is 0.777). The exploratory factorial analysis revealed a bidimensional structure of the BT concept which is different from the original scale that was developed by Gurviez and Korchia (2002). Concerning the 
BA variable, the performed procedure revealed an excellent reliability rate that reaches 0.880 when calculated by the Cronbach's Alpha without the removal of any item of the five original ones which proves the consistency as well as the robustness of the Lacoeuilhe (2000) scale. The Kapferer and Laurent (1992) scale of BS also stuck to its original structure composed of only one dimension but it lost two of its five original items as they do not correlate at all with the generated factor. The loss of some items of this scale is not also new; in fact in the research of Joel Gouteron (2006), the final structure was composed of only four items.

The application of the Confirmatory Analysis (CA) on the structure of the RBP scale that is composed of 14 items distributed on three factors; excitation, modernity and fallacious character furnished an acceptable and satisfactory adjustment quality (GFI O.888; RMSEA 0.083; NFI 0.836; Normed X2 3.201). Concerning the BA measurement instrument, the application of the confirmatory analysis gave a dreadful adjustment quality that seems to be influenced by the third item of the scale which is "I' $m$ very linked to this (these) brand(s)" that presented a t-Student (Critical Ratio) inferior to 1.96. Consequently, the latter was removed and a second Confirmatory Analysis was run. The retained structure after this modification presents a good adjustment quality as barely all the indices reached the critical levels (GFI 0.979; RMSEA 0.081; NFI 0.988; Normed X2 4.315). BT confirmatory analysis gave a satisfactory output (GI 0.886; RMSEA 0.091; NFI 0.912; Normed X2 4.867). Finally, the brand sensitivity BS scale kept all its items and presented a satisfactory adjustment quality (GFI 0.994; RMSEA 0.042; NFI 0.966; Normed X2 1.453)

Concerning the reliability and validity of scales, the realized tests indicate that for reliability almost all the studied scales are reliable since they posted excellent values largely superior to 0.7 which means that despite the population change, the measurement instruments are able to reproduce barely the same measures. Concerning convergent validity, all the scales and factors are able to reproduce almost the same results despite the change of the format measure.

Table 1: Reliability and convergent validity

\begin{tabular}{|l|c|c|}
\hline $\begin{array}{c}\text { Scales and } \\
\text { Dimensions }\end{array}$ & $\begin{array}{c}\text { P of } \\
\text { Joreskog }\end{array}$ & $\begin{array}{c}\text { P of Convergent } \\
\text { Validity }\end{array}$ \\
\hline Excitation & 0.691 & 0.501 \\
\hline Modernity & 0.687 & 0.749 \\
\hline Fallacious Character & 0.583 & 0.370 \\
\hline Brand Personality & 0.772 & 0.513 \\
\hline Credibility & 0.756 & 0.621 \\
\hline Integrity & 0.821 & 0.715 \\
\hline Brand Trust & 0.887 & 0.668 \\
\hline Brand Attachment & 0.762 & 0.554 \\
\hline Brand Sensibility & 0.959 & 0.851 \\
\hline
\end{tabular}

\section{The Hypotheses Test}

The test of the conceptual model was done through the Structural Equations Method. The results are presented below:

$\mathrm{H}_{1}$ : The first hypothesis assumes a positive impact of $\mathrm{BP}$ on the relationship brand-consumer through its impact on BT. This Hypothesis is verified as the following table shows. In fact, a retailer brand that is perceived to be exciting, young $(0.210, \rho<$ as expected the more a distributor brand is seen as fallacious, incompetent and deceiving, the less the trust feeling is to be developed as trust is built on credibility, benevolence, frankness and expressed respect.0.05) and modern $(0.783, \rho<0.05)$ stimulates the creation and the development of a relationship built on trust.

Table 2: The structural model output related to the first hypothesis

\begin{tabular}{|c|c|c|c|}
\cline { 2 - 4 } \multicolumn{1}{c|}{} & $\begin{array}{c}\text { Unstandardized } \\
\text { coefficients }\end{array}$ & $\begin{array}{c}\text { Critical } \\
\text { ratio }\end{array}$ & $\mathrm{P}$ \\
\hline Trust $\leftarrow$ Excitation & 0,210 & 3,622 & 0,000 \\
\hline Trust $\leftarrow$ Modernity & 0,783 & 11,242 & 0,000 \\
\hline Trust $\leftarrow$ Fallacious & $-1,500$ & $-2,831$ & 0,005 \\
\hline
\end{tabular}

$\mathbf{H}_{2}$ : In regarding to the second hypothesis, it postulates the existence of a positive BP influence on the relationship brand-consumer through its impact on BA. This hypothesis is also validated in the current context and for RB. In fact, a brand is trusted and seen as credible and honest as it is exciting, beautiful, young $(0,150, \rho=0,000)$, modern and serious $(0,340, \rho=0,000)$. Results that cohere with Gouteron (2006) findings despite the use of a different BPS, different brands and sector in his research.

Table 3: The structural model output related to the second hypothesis

\begin{tabular}{|c|c|c|c|}
\cline { 2 - 4 } \multicolumn{1}{c|}{} & $\begin{array}{c}\text { Unstandardized } \\
\text { Coefficients }\end{array}$ & $\begin{array}{c}\text { Critical } \\
\text { Ratio }\end{array}$ & $\mathrm{P}$ \\
\hline Attach $\leftarrow$ Excitation & 0,150 & 3,703 & 0,000 \\
\hline Attach $\leftarrow$ Modernity & 0,340 & 7,258 & 0,000 \\
\hline Attach $\leftarrow$ Fallacious & $-1,570$ & $-2,923$ & 0,003 \\
\hline
\end{tabular}

$\mathbf{H}_{3}$ : Before proceeding to the third and fourth hypotheses, it was compulsory to divide the sample into two groups (highly sensitive/ weakly sensitive). This was done through the Quick cluster method. The results of the Quick Cluster gave two groups composed of 154 consumers judged to be sensitive and 102 not as the following table shows:

Table 4: The quick cluster output

\begin{tabular}{|c|c|c|}
\hline Cluster & $\begin{array}{c}\text { Number of cases } \\
\text { in each cluster }\end{array}$ & $\begin{array}{c}\text { Percentage of cases } \\
\text { in each cluster }\end{array}$ \\
\hline $\begin{array}{c}\text { Cluster 1: } \\
\text { Strongly Sensitive }\end{array}$ & 154 & 60,16 \\
\hline $\begin{array}{c}\text { Cluster 2: } \\
\text { Weakly Sensitive }\end{array}$ & 102 & 39,84 \\
\hline Total & 256 & 100 \\
\hline
\end{tabular}


For the third hypothesis, the table below shows firstly an insignificant impact of fallacious character on BT for the first population $(\rho=0.642>0.05)$ and another insignificant positive impact of excitation on trust for the same population $(\rho=0.187>0.05)$ which means that for strongly brand sensitive consumers, modernity, elegance and seriousness matter and determine the creation and the development of a trust feeling toward this brand. On the contrary, for the weakly brand sensitive consumers, everything matter and every detail influences the creation of confidence feeling, they pay attention to many factors at the same time, excitation, beauty, modernity and seriousness and if a brand is judged to be deceiving, this will definitely prevents the birth of trust. Overall, the brand Sensitivity seems to play a moderating role in the relationship brand personality- brand Trust as the results of the two populations are not alike and every type of consumers laid their confidence on exclusive factors.

Table 5: The structural model output related to the third hypothesis

\begin{tabular}{|c|c|c|c|c|c|c|}
\cline { 2 - 7 } \multicolumn{1}{c|}{} & \multicolumn{3}{c|}{\begin{tabular}{c} 
Group1: \\
\multicolumn{1}{c|}{ Strongly sensitive }
\end{tabular}} & \multicolumn{3}{c|}{$\begin{array}{c}\text { Group 2: } \\
\text { Weakly sensitive }\end{array}$} \\
\cline { 2 - 7 } \multicolumn{1}{c|}{} & $\begin{array}{c}\text { Unstandardized } \\
\text { coefficients }\end{array}$ & CR & P & $\begin{array}{c}\text { Unstandardized } \\
\text { coefficients }\end{array}$ & CR & $\mathrm{P}$ \\
\hline $\begin{array}{c}\text { Trust } \leftarrow \\
\text { Excitation }\end{array}$ & 0,012 & 0,187 & 0,852 & 0.39 & 3,896 & 0,000 \\
\hline $\begin{array}{c}\text { Trust } \leftarrow \\
\text { Modernity }\end{array}$ & 1,132 & 9,667 & 0,000 & 0.74 & 6,551 & 0,000 \\
\hline $\begin{array}{c}\text { Trust } \\
\text { Fallacious }\end{array}$ & $-0,033$ & $-0,464$ & 0,642 & -1.11 & $-2,552$ & 0,011 \\
\hline
\end{tabular}

$\mathbf{H}_{4}$ : this hypothesis refers to the impact of the consumer brand sensitivity profile on the relationship between perceived retailer brands personality and brand attachment. Unlike the precedent hypothesis (H3), this one was not validated as the table shows.

Table 6: The structural model output related to the fourth hypothesis

\begin{tabular}{|c|c|c|c|c|c|c|}
\cline { 2 - 7 } \multicolumn{1}{c|}{} & \multicolumn{3}{c|}{$\begin{array}{c}\text { Group1: } \\
\text { Strongly sensitive }\end{array}$} & \multicolumn{3}{c|}{$\begin{array}{c}\text { Group 2: } \\
\text { Weakly sensitive }\end{array}$} \\
\cline { 2 - 7 } \multicolumn{1}{c|}{} & $\begin{array}{c}\text { Unstandardized } \\
\text { coefficients }\end{array}$ & CR & $\mathrm{P}$ & $\begin{array}{c}\text { Unstandardized } \\
\text { coefficients }\end{array}$ & $\mathrm{CR}$ & $\mathrm{P}$ \\
\hline $\begin{array}{c}\text { Attach } \leftarrow \\
\text { Excitation }\end{array}$ & 0,081 & 2,184 & 0,029 & 0.18 & 2,597 & 0,009 \\
\hline $\begin{array}{c}\text { Attach } \leftarrow \\
\text { Modernity }\end{array}$ & 0,483 & 6,080 & 0,000 & 0.480 & 5,539 & 0,000 \\
\hline $\begin{array}{c}\text { Attach } \leftarrow \\
\text { Fallacious }\end{array}$ & $-0,1$ & $-2,319$ & 0,020 & -1.371 & $-2,826$ & 0,005 \\
\hline
\end{tabular}

\section{Discussion, Limitations and FutUre Research AVENUE}

This research is to a certain extent new in Tunisia as it takes in charge to analyze the retailer brands personality and the impact that it could play in developing and maintaining a long-term relationship with the store and the brand itself. The results that were presented above tie with those of previous studies undertaken for national brands and ordinary ones. The research in hand highlights that the more the brand's traits are clear in the consumers' mind and subconscious, the more they are ready to give the brand a chance to be tried and why not later on adopted and included in the routine basket. In fact, brands with well promoted distinctive characteristics are more likely to attract potential consumers to build a tie with.

Retailer brands in Tunisia are to certain level new and not seen as equal to the well-known brands. The Tunisian consumer is getting now used to the fact that Retailer brands can be classified into diverse categories going from one having a modest quality to products that surpass many famous brands well-established in the Tunisian market. In fact, by contacting the communication manager of Carrefour in 2016, he informed us that even strategically the diverse categories are not managed equally. From a merchandizing angle, La marque $\mathrm{N}^{\circ} 1$ (the first to be marketed in Tunisia in the late 2008) which is cheap, with so simple packaging is always put at the botton linear which is the last option for consumers who have a limited budget or perceive the product category as not worth to be invested highly in. On the contrary, the new brands that are released simultaneously in France and Tunisia, which are expensive and do have extremely studied and glamourous packaging with a high quality are put just in front of the consumers' eyes on the highest linear.

As we worked in an exploratory context, our study have some limitations. First, the participants were unfamiliar with the notion of Brand personality and saw it as a strange topic and sometimes ironic that they tried to botch. Second, the precocity of the treatment of the Distributor Brands' Personality, attachment and trust gave also birth to many other problems during the survey. In fact, many people do ignore the existence of those brands; others were ready and better prepared to give their opinions about their quality, their packaging as well as expressing and showing their satisfaction levels. Finally, the survey took place in the hypermarkets (Carrefour, Géant, Champion) which could influence the respondents' answers who were shopping and had not much time to devote to questionnaires especially about new brands that they do not know very well.

Despite those limits but this research have several bnefits. First, the knowledge of the perceived brand's personality is a vital piece of information that helps the managers know the strong and distinctive points of their strategic weapons and hence maintain and strengthen them as well as their weaknesses that must be overcame. Consequently, the Distributor brands' managers become able to adjust their positioning strategy and wished personality to those perceived by their customers. Second, the Retailer brands' managers can lean on the research's results to know exactly the perceived personality facets that influence the most the creation and the evolvement of trust and attachment feelings. Finally, the retailer brands' managers can use the generated personality scale to know the personality of every broadcasted brand and use the results in their advertising campaign. Thus, their future advertising axe 
won't be grounded on the mere advantageous quality/price ratio or the attractive cost-benefit one but on more realistic and reliable information taken directly from the customers' mouths and minds.

Finally, this research opens the door for posterior and subsequent researches that can be mentioned as follows. First, it will be interesting to examine other brand personality consequences as brand loyalty and see to which extent a brand with strong and attractive personality traits can prevent the customer from switching to another competitive brand. Second, the knowledge of the brand personality consequences and ability to stimulate, create and develop a brand-customer relationship is vital and important but the knowledge of the factors and reasons that influence the brand anthropomorphization is of a huge importance too. By knowing the motives that let the customer look at a brand as a human being, the managers become able to manipulate them and hence approach their fixed personality to the consumers' perceived one. Third, It seems also advantageous to study the brand personality concept outside the B to $\mathrm{C}$ context and examine in a B to B one to which extent professional purchasers personify brands and if this concept is still exist, does it maintain its influential power on the relationship brand-customer. Finally, in a research aiming the identification of a relational chain leading to loyalty, Aurier and al (2001) have demonstrated that trust comes before brand attachment, hence, it will be beneficial in a posterior research to add to the current conceptual model a tie linking confidence to attachment and make sure empirically of the existence of such causality.

\section{REFERENCES}

Aaker, J.L. (1997), “Dimensions of brand personality”, Journal of Marketing Research, Vol. 34. 347-56.

Aaker, J.L., Fournier, S. and Brasel, S.A. (2004), "When good brands do bad", Journal of Consumer Research, Vol. 31. 1-16.

Albert. N; Merunka. D and Valette-Florence.P (2008): “When consumers love their brands: Exploring the concept and its dimensions". Journal of Business Research. V1 61. 1062-1075.

Allenby. G. M. and Lenk. P. J. (1995): Reassessing Brand Loyalty, Price Sensitivity, and Merchandising Effects on Consumer Brand Choice. Journal of Business \& Economic Statistics, Vol. 13, No. 3. 281-289.

Ambroise. L. (2006) : La personnalité de la marque : contributions théoriques, méthodologiques et managériales. Recherche et Applications en Marketing; Vol21, No2. pg96

Ambroise. L. (2006): La personnalité des marques: une contribution réelle à leur gestion? Revue Française du Marketing; Vol 207. 25-41

Ambroise.L ; Pantin-Sohier. G and Valette-Florence. P. (2007): De la personnalité des célébrités à la personnalité des marques : Nouvelle démarche de sélection des ambassadeurs. Actes du XXIIIème Congrès International de 1'AFM - 31 mai \& 1er juin 2007, Aix-les-Bains

Azoulay. A. and Kapferer. J-N (2003): Do brand personality scales really measure brand personality. Brand Management, Vol11, No 2, 143-155.
Barnes. T. (1999): Book Review: Space and social theory: interpreting modernity and postmodernity. Sage Publication

Baugartner. H. (2002): Toward a Personology of the Consumer. Journal of consumer research, Vol. 29. 286-292

Becquart. L. (2007): Marques de distributeurs, jusqu'ou iront elles? MDD Rencontres 27/03/07. 1-7

Belk R.W. (1988): "Possessions and the Extended Self". Journal of Consumer Research, Vol 15, 139-168

Belk R.W. (1990): “The Role of Possessions in Constructing and Maintaining A Sense of past". Advances in Consumer Research, Vol 17, 669-676.

Belk. R. W.; Wallendorf. M and Sherry. J.F. (1989): The Sacred and the Profane in Consumer Behavior: Theodicy on the Odyssey. The Journal of Consumer Research, Vol. 16, No1.1-38

Bergès-Sennou. F.; Bontems. P. and Réquillart. V. (2007): L'impact économique $\mathrm{du}$ développement des marques de distributeurs . Université de Toulouse. Avril.1-30

Blythe. J. (2007): Advertising creatives and brand personality: A grounded theory perspective. Journal of Brand Management. Vol14, 284- 294.

Boeree. G. (2006): Personality Theories. Psychology Department Shippensburg University, E-Text

Bressoles.G: " L'instauration d'un climat de confiance en ligne : Le rôle des signes de qualité des sites internet marchand". Papiers de recherche

Bretherton. I. (1992): The origins of attachment theory: John Bowbly and Mary Ainsworth". Developmental Psychology (1992), Vol 28, 759-775

Brody. R. P and Cunningham. S.M (1986): Personality variables and the consumer decision process. Journal of Marketing Research. Vol 5.No1. 50-57

Brown S., Kozinets. R. and Sherry. J. (2003): “Teaching old brands new tricks: retro branding and the revival of brand meaning". Journal of Marketing, Vol 67, 19-33.

Bryan Hayes. J.; Alford. B. L.; Silver. L and York. R P. (2006): Looks matter in developing consumer-brand relationships. Journal of Product \& Brand Management. Vol $15 \cdot$ No $5 \cdot 306-31$

Campbell, D. T. and Fiske, D. W. (1959): “Convergent and discriminant validation by the multi-trait multi-method matrix". Psychological Bulletin, Vol 56, 81-105.

Capelli. S. and Pantin-Sohier. G (2003) : Le tempérament de la marque enseigne: Une première étude. 1-25

Chaudhuri. A.and Holbrook. M. B (2002): Product-class effects on brand commitment and brand outcomes: The role of brand trust and brand affect. Journal of Brand Management; Vol10. No1. 33-58

Churchill. G.A.Jr (1979): “A paradigm for developing better measure of marketing constructs" .Journal of Marketing Research. Vol16. 64-73

Coloigner. T. and Woelfel. G (2001): Distribution : les producteurs cherchent leurs marques. Annales des Mines

Cristau. C. (2001): Définition, mesure et modélisation de l'attachement à une marque comme une conjonction de deux dimensions distinctes et concomitantes : la dépendance et l'amitié vis-à-vis de la marque. Papier de recherche n591, I.A.E Aix-en-Provence. 
Delgado- Ballester. E. and Munuera-Aleman. J. L. (2002): Development and validation of a brand trust scale across product categories: A confirmatory and multigroup Invariance Analysis. American Marketing Association. Conference Proceedings; 519

Delgado- Ballester. E. and Munuera-Aleman. J. L. (2005): “Does brand trust matter to brand equity?" Journal of Product \& Brand Management. Vol14.No3. 187-196

Delgado-Ballester. E. (2002): “Development and validation of a brand trust scale".1-58

Doney and Cannon (1997): "An examination of the nature of trust in buyer seller relationships", Journal of Marketing, vol61, 3-51

Dwayne Ball. A. and Tasaki. L. H. (1992): The Role and Measurement of Attachment in Consumer Behavior. Journal of Consumer Psychology, Vol. 1, No. 2 155-172

Evrard .Y (1993) : La satisfaction des consommateurs : état des recherches, Revue Française du Marketing, No144-145, 54-66

Ferrandi. J-M ; Merunka. D. and Valette-Florence. P. (2003) : La personnalité de la marque : bilan et perspectives. Revue française de gestion 2003/4 ; No 145. 145-162

Filser. M.and Anteblian. B. (1998): Marques de producteurs, marques de distributeurs, marques premier prix. Actes de la 3ème Journée de Recherche en Marketing de Bourgogne. Dijon.1-187

Fournier S. (1998): "Consumers and their brands: developing relationship theory in consumer research". Journal of Consumer Research, Vol 24, 343-373

Freling. T. H and Forbes. L. P (2005): "An empirical analysis of the brand personality effect". The Journal of Product and Brand Management; Vol14.No 7. 404-413

Fuat Frrat. A. and Dholakia. N. (2006): Theoretical and philosophical implications of postmodern debates: some challenges to modern marketing. Vol 6, No2; 123-162

Fuat Firat; Dholokia and Venkatesh (1993): "Marketing in a postmodern world". European Journal of Marketing. Vol29.No1. 40-56

Ganesan. S (1994): Determinants of long term orientation in Buyer-Seller Relationship. Journal of Marketing, Vol 58, No 2, 1-19

Gharbi. J- E (2007) : Théorie Marketing : Le Débat de Fond. Livre en cours de publication

Gouteron. J. (2006) : La personnalité de la marque, outil stratégique sur le marché du prêt-à-porte féminin. La Revue des Sciences de Gestion : Direction et Gestion; No222. 47-60

Gouteron. J. (2006) : L'impact de la personnalité de la marque sur la relation marque-consommateur: Application au marché du prêt-à-porter féminin. Revue Française du Marketing; No207. 43-59

Guo. X. (2006) : La sensibilité aux marques et l'engagement à la marque : une application aux consommateurs chinois. Recherche et Applications en Marketing; Vol21.No1. 108

Gurviez. P. and Korchia. M. (2002) : Proposition d'une échelle de mesure multidimensionnelle de la confiance dans la marque. Recherche et Application en Marketing, Vol17, No3. 41-62

Gurviez. P. and Korchia. M. (2002): Proposition of a multidimensional brand-trust scale. Recherche et Applications en Marketing; 2002; Volume 17, No 3; 113-121
Guyon. H. (2005): “Approche expérimentale de l'influence de la personnalité de marque sur le capital-marque et de ses conséquences en termes de parts de préférence. Recherche et Applications en Marketing. Grenoble: Sep 2005. Vol. 20, N ${ }^{\circ}$ 3; 102-104

Hallberg. G (1995): All Consumers are not created equal: The differential marketing strategy for brand loyalty and profits"

Hogan.J; Barrett.P and Hogan. R (2007):“Personality measurement, faking and employment selection". Journal of Applied Psychology. Vol92. No5. 1270- 1285

Holbrook, M. B and Hirschman, E. C. (1982): “The experiential aspects of consumption: Consumer fantasies, feelings, and fun". Journal of Consumer Research, 9, 132-140.

Holbrook. M. B. (1993): Nostalgia and Consumption Preferences: Some Emerging Patterns of Consumer Tastes. The Journal of Consumer Research, Vol. 20, No. 2 245-256

Hoon. S.; Ang E.and Ching Lim.A (2006): “The influence of metaphors and product type on brand personality perceptions and attitudes". Journal of Advertising. Vol. 35, $\mathrm{N}^{\circ} 2 ; 39-50$.

Jo Bitner. M. (1995): Building Service Relationships: It's all about promises. Journal of the Academy of Marketing Science. Vo23, No4, 246-251

Kapferer J-N (2004) : Les marques face au hard discount Quelles stratégies? Revue Française de Gestion; Vol 30. 203-210

Kapferer. J.N (1996) "Les marques capital de l'entreprise, les chemins de la reconquete" 2ème edition, Paris, les éditions d'organisation.

Kapferer. J-N (2002): Reinventing the brand:Can top brands survive the new market realities. Journal of Brand Management; Vo19. No2.481-484

Kassarjian. H. H. (1971): Personality and Consumer Behavior: A Review. Journal of Marketing Research, Vol. 8, No. 4 (Nov., 1971), 409-418. Published by: American Marketing Association.

Kessous. A. and Roux. E. (2006): La nostalgie comme antécédent de l'attachement à la marque. Papier accepté au 5ème Congrès sur les Tendances du Marketing en Europe, Venise, 20-21 Janvier.

Kitchin. T. (2003): Corporate social responsibility: A brand explanation. Journal of Brand Management; Vol10.No 4/5. 312-326

Kleine. R. E. ; Kleine. S. S. and Kernan. J. B. (1993): Mundane Consumption and the Self: A Social-Identity Perspective. Journal of Consumer Psychology. Vol. 2. No. 3.209-235

Kleine. R. E.and Kleine. S. S (1999): Consumption and Self-Schema Changes throughout the Identity Project Life Cycle. The 1999 Annual Conference of the Association for Consumer Research. 1-23

Kleine. S. S; Kleine. R. E. and Allen. C. T. (1995): How is a Possession "Me" or "Not Me"? Characterizing Types and an Antecedent of Material Possession Attachment. The Journal of Consumer Research, Vol. 22, No. 3.327-343

Koebel. M. N and Ladwein. R. (1999): L'échelle de personnalité de la marque de Jennifer Aaker: Adaptation au contexte français, Décision Marketing. $\mathrm{N}^{\circ} 16.81-88$

Kumar. R.; Luthra. A. and Datta. G. (2006): Linkages between Brand Personality and Brand Loyalty: A Qualitative Study in 
an Emerging market in the Indian Context. South Asian Journal of Management; Vol13.No 1.11-35

Lacey. R. (2007): Relationship drivers of customer commitment. Journal of Marketing Theory and Practice; Vol15.No 4; 315-333

Lacoeuilhe J. (2000), L'attachement à la marque : proposition d'une échelle de mesure. Recherche et Applications en Marketing, Vol15, No4, 61-77.

Lacoeuilhe. J. and Belaïd.S (2007) : "Quelle(s) Mesure(s) pour l'attachement à la marque ?". Revue Française du Marketing; Vol2. No213.7-25

Lacoeuilhe. J. and Cristau.C (2007) : Attachement et fidélité aux marques de distributeurs: Première proposition de cadre perceptuel Papier de recherche. 1-27

Lacoeuilhe.J (1997), Le concept d'attachement à la marque dans la formation du comportement de fidélité, Revue Française du Marketing, Vol165, No5, 29-42.

Lamarque. P (2000): Maires: les essentiels de votre communication, le guide pratique. Editions Stratégies

Levy. S., J. (1959): Symbols for sales Harvard Business Review, Vol37.No4.117-124

Louis. D. and Lombard. C. (2007) : "Impact de la personnalité de la marque sur la satisfaction et la fidélité u consommateur Papier de recherche. 1-30

Magali. J. (2004): Comparaison des positionnements concurrentiels des marques de distributeurs, selon les perceptions des clients Carrefour et la diffusion effective des magasins. Allocataire de recherche et monitrice

McCracken. G. (1986): Culture and Consumption: A Theoretical Account of the Structure and Movement of the Cultural Meaning of Consumer Goods. Journal of Consumer Research, Vol. 13, No. 1.71-84. Published by: The University of Chicago Press

Meritet. S (2007): Nouvelle Concurrence Verticale entre producteurs et distributeurs français: L'enjeu des marques de distributeurs. Université IX- Dauphine.1-3

Moorman C.; Deshpandé R. and Zaltman G. (1992): “Relationship between providers and users in market research: the dynamics of trust within and between organizations". Journal of Marketing Research, Vol.29, 314-328.

Morgan R. M and Hunt. S (1994): The commitment-trust theory of relationship marketing. Journal of Marketing. Vol 58, No 3; 20-38

Murray. J. B. (2002): “The Politics of Consumption: A Re-Inquiry on Thompson and Haytko's (1997) "Speaking of Fashion". Journal of Consumer Research, Inc. Vol. 29. 427-440

Okazaki. S. (2005): Excitement or sophistication? A preliminary exploration of online brand personality. International Marketing Review Vol. 23 No. 3.279-303

Opoku. R.; Abratt. R. and Pitt. L. (2006): "Communicating brand personality: Are the websites doing the talking for the top South African Business Schools?" Journal of Brand Management. London. Vol. 14, No 1/2. 20-39
Osler. R. (2007): The type-role-purpose brand taxonomy. Journal of Brand Management. Vol14.430 - 441.

Pache. G. (2003) : Les MDD chez Carrefour : une belle histoire et un avenir prometteur. 5eme Colloque Etienne THIL. La Rochelle, 24 et 25 septembre 2003

Pantin-Sohier. G.and Brée. J. (2004) : L'influence de la couleur du produit sur la perception des traits de personnalité de la marque. Revue Française du Marketing; Vol196.No1/5. 19-32.

Phau. I. and Lau. K.C. (2001): Brand personality and consumer self-expression: Single or dual carriageway?" Brand Management. Vol. 8, No. 6, 428-444.

Plummer J.T (1984): How personality makes a difference. Journal of Advertising Research. Vol24.No6. 27-31

Ramaseshan. B.and Tsao.H-Y (2007): Moderating effects of the brand concept on the relationship between brand personality and perceived quality. Journal of Brand Management, Vol 14, $458-466$.

Raufaste. E: La modélisation en équations structurelles

Reast. J. D (2005): Brand trust and brand extension acceptance: the relationship. The Journal of Product and Brand Management; Vol14.No1. 4-13

Romaniuk. J. and Bogomolova. S. (2005): Variation in brand trust scores. Journal of Targeting, Measurement and Analysis for Marketing; Aug 2005; Vol 13, No4. 363-373.

Sirdeshmukh. D.; Singh. J.and Sabol. B. (2002): Consumer Trust, Value, and Loyalty in Relational Exchanges. The Journal of Marketing, Vol. 66, No. 1 ; 15-37.

Siriex and Dubois. P.L. (1999), Vers un modèle qualité satisfaction intégrant la confiance, Recherche et Applications en Marketing, N³, 1-13

Smaoui. F. (2006) : La mesure de la personnalité de la marque dans lecontexte tunisien: proposition d'une échelle de mesure, premiers résultats. 4ème colloque International de la Recherche en Marketing Association Tunisienne de Marketing. Mars

Smaoui. F. (2008): Les déterminants de l'attachement émotionnel à la marque: Effets des variables relationnelles et des variables relatives au produit $7^{\text {ème }}$ Congrès des Tendances Marketing, Venise 17-18. Janvier

Stern. B.B (2006): “What Does Brand Mean? Historical-Analysis Method and Construct Definition". Academy of Marketing Science. Journal. Greenvale: Vol. 34, N²; 216-22

Thiétart, RA, (2003) : Méthodes de recherche en management, 2e édition, Dunod, P.216.

Tian. K.and Belk. R. W (2005): Extended Self and Possessions in the Workplace. Journal of Consumer Research; Vol32.No 2; 297-310

Trabelsi. M (2010) master dissertation "The brand anthropomorphization and the consumer-brand relationship". Institut Supérieur de Gestion de Tunis.

$--0--$ 
How to Cite: Trabelsi, M. (2019). The Brand Personality: a Key Catalyst of the Consumer-brand Relationship. American Journal of Trade and Policy, 6(1), 13-22.

\section{SOCIAL SCIENCE RESEARCH NETWORK 2171 Monroe Avenue, Suite 203, Rochester, NY 14618, USA http://www.ssrn.com/en/}

SSRN Link: http://www.ssrn.com/link/American-Journal-Trade-Policy.html 